\title{
Hegemony of two avian species: Black kites and Cattle egrets on two distant landfills during COVID-19 pandemic in Gujranwala, Pakistan
}

\author{
Zunaira Noreen $^{1 *}$ and Khawar Sultan ${ }^{1}$ \\ 1. Department of Environmental Sciences, University of Lahore, Defence Road Campus, Lahore, Pakistan \\ *Corresponding author's email: zunaira.norin@ gmail.com \\ Citation \\ Zunaira Noreen and Khawar Sultan. Hegemony of two avian species: Black kites and Cattle egrets on two distant \\ landfills during COVID-19 pandemic in Gujranwala, Pakistan. Pure and Applied Biology. Vol. 11, Issue 1, pp11-25. \\ http://dx.doi.org/10.19045/bspab.2022.110002
}

Received: 06/01/2021

Revised: 26/03/2021

Accepted: 02/04/2021

Online First: 17/05/2021

\section{Abstract}

The pandemic of COVID -19 has brought many changes to wildlife globally positively or negatively. During lock downs the abundance of many wild species has increased due to decease in human disturbance in area. This study is designed to compare two landfills situated $22 \mathrm{~km}$ apart in the Gujranwala, Punjab in terms of avifauna diversity, abundance and foraging behavior during COVID-19 pandemic. The field observations using the total count method of population census revealed the abundance of contrasting avian species at both sites with a very low values of the diversity index $(\mathrm{H}=1.146$ Chianwali \& $\mathrm{H}=1.697$ Gondalawala ) and species evenness $(\mathrm{E}=0.423$ Chianwali \& $\mathrm{E}=0.587$ Gondalawala). A large variation in bird's population was recorded at both landfills, i.e. $\mathrm{N}>17,300$ at one landfill (Chianwali) and $\mathrm{N}>26,200$ at the other (Gondalawala). Time dependent variation in population was also observed. Cattle egret was dominant species ( $75 \%$ of population) at the Chianwali landfill site while the Black kite ( $55 \%$ of population) was the dominant species at Gondalawala landfill. House crow was the second dominant species at both sites. Birds were grouped into categories based on ecological behaviors such as dominance, opportunists, insectivory etc. The study finds that each landfill has its own specific character depending upon the geographical location, accessibility of birds to landfills, and management practices such as presence of boundary wall and artificial lights. Moreover, it also finds that COVID - 19 lockdown provided an opportunity to wild avian species to exploit human rehabilitated areas abundantly where there presence was very few because of dominance of human beings and their activities.

Keywords: Abundance; Behavior; Birds; Black kites; Cattle egrets; COVID-19 Pandemic; Landfill; Food waste

\section{Introduction}

Human food subsidies associated with landfills attract a large number of wild avian species for foraging $[1,2]$. The exploitation of landfills by avifauna for food $[3,4]$ shelter and breeding [5] has been reported from the various regions of the world. This shifting of birds from the natural habitat to the anthropogenic habitat (landfills) is changing the biology of species. It is facilitating the population explosion in many species like gulls, storks, and crows [6-8] at one side and threatening the population of other endangered species like vultures by ingesting the harmful materials from the landfills [9, 10] on another side. The availability of food 
rich in calories from landfills is also affecting the ecology of birds by changing their migratory routes $[11,12]$. The shift of diet from natural resources towards the debris, waste and plastic has been documented in many species of birds $[3,4,13]$. The development of new learning mechanisms $[14,15]$ and behavioral changes have also been adopted by many bird species for best exploitation of food from landfills.

The studies conducted around the world show that each landfill and the associated wild avifauna have their own specific characteristics that depend mainly upon the geographical location, ease of accessibility, native wildlife profile and solid waste composition. The studies conducted in the European region, for example, showed that different gull species, i.e. Herring gulls (Larus argentatus), Lesser black -backed gulls (Larus fuscus), Common gulls (Larus canus), Great Black-backed gulls (Larus marinus) [1, 16] and Yellow-legged gulls [2] are most successful in exploiting landfills for foraging. In Spain and Poland White stork (Ciconia ciconia) is dominant species using landfills [12]. Black kites (Milvus migrans), Black vulture (Coragyps atratus) [17] and Rooks (Corvus frugilegus) [18] are the other dominant species present at landfills of different European countries. In the African region, Pied crow (Corvus albus) and Cattle egret (Bubulcus ibis) are the most dominant species present at landfills [19, 20]. In Asia, Crows (Jungle crow and House crow) are successful in exploiting inland landfills. In South East Asia, however, the research is limited and the impact on native avifauna is not clear. However, recently the abundance of many species like House crow (Corvus splendens) Common myna (Acridotheres tristis), plain martin (Riparia paludicola) and Bank myna (Acridotheres ginginianus) has also been reported at a landfill in Gujranwala, Pakistan [21].
To find out the characteristics of each landfill, in terms of avian species, abundance and behavior on landfills of the same region, this investigation was carried out at two landfills located $22 \mathrm{~km}$ away from each other in northeast Punjab, Pakistan. Moreover the focus of study was also to find out the difference of abundance and variety of birds on landfills during the lockdown in the pandemic of covid-19. The study will find whether the less human disturbance has facilitated the aggregation of avian species in the region within lockdown as reported in many other areas of the world.

\section{Materials and Methods Study area}

The study area is located in district Gujranwala, a northeastern part of Punjab, Pakistan (Fig. 1). The total area is $3,198 \mathrm{~km}^{2}$, elevation is $226 \mathrm{~m} \mathrm{ASL}$ and the population is $2,238,243$, which makes it the seventh mostpopulous metropolitan area in Pakistan. Gujranwala has a hot semi-arid climate [22] with long summer season (May to September; average temperature $37^{\circ} \mathrm{C}$ ) and moderate winter season (November to February; average temperature $7 \quad{ }^{\circ} \mathrm{C}$ ). Average annual rainfall is $581 \mathrm{~mm}$ with the highest amount in July and August due to the arrival of monsoon and the driest months are October to November, with very little rain (<10 mm per month) [23]. Gujranwala is among the most populated cities of Pakistan so urban waste production is very high ( 21,000 tons per day) [24]. The urban solid waste is disposed of at three landfills, located round the city, namely, Chianwali, Bhakrywali and Gondalawala. During the sampling Bhakrywali landfill was not an active site in terms of operation of solid waste disposal and is, therefore, not a part of this study. The field data observations were carried out at Chianwali and Gondalawala landfill sites. Waste is transported from the city and surrounding rural areas by use of vehicles such as trucks and trollies. The 
landfill operation method carried out at two sites is the open dumping with no covering of any soil or some other material. The open dumping with a plenty of food present in the urban waste provide a feast to wild birds for feeding hence changing these landfills to habitat (Fig. 1).

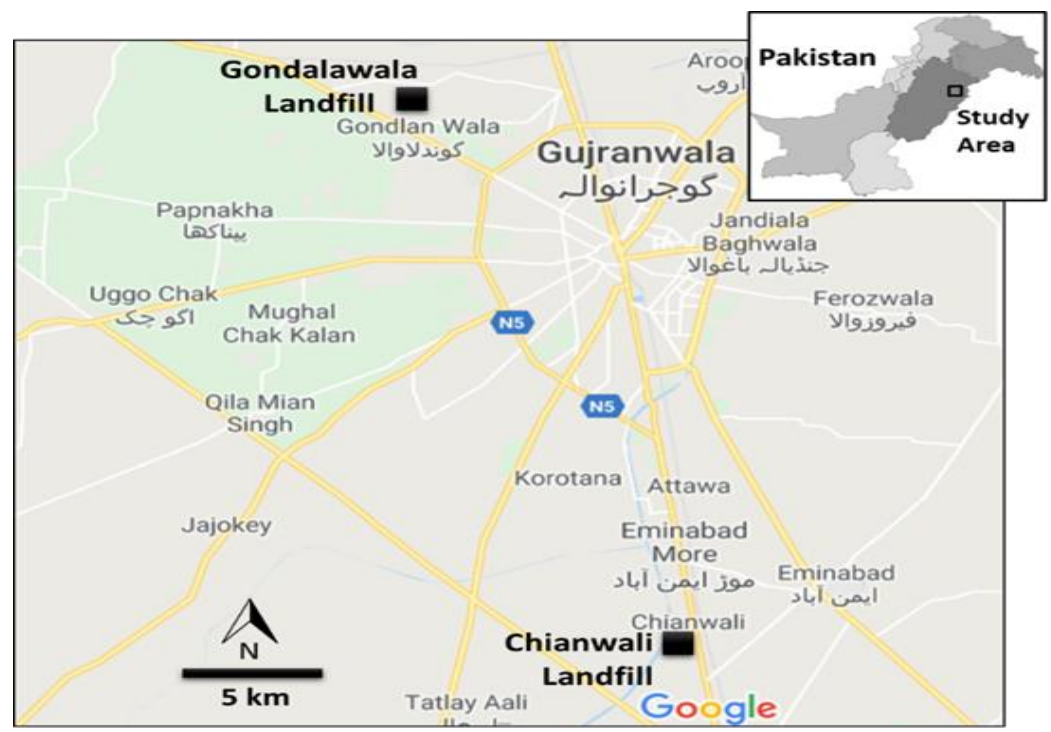

Figure 1. Location of two landfill sites in Gujranwala area

\section{Sampling sites}

The sampling was done at both active landfills (Gondalawala and Chianwali) of Gujranwala city located at a distance of 22 $\mathrm{km}$ away from each other (Fig. 1) in MarchApril 2020 in days of lockdown due to global pandemic of COVID-19. Chianwali landfill site is lowland along the Grand Trunk Road, a national highway, situated about $15 \mathrm{~km}$ south of the city center (Fig. $1 \& 2$ ). The landfill is a semi-constructed, open-air dumping site with an area of $102,870 \mathrm{~m}^{2}$. Solid waste material is contained in the boundary wall to isolate it from the main road and public housing. The main land use in the surrounding area is local industry, rural housing and a water canal for irrigation. But in the pandemic a very few people and vehicle was present on the road. Industries were also closed so the situation was different from the past ever. Only Vehicles such as trollies take waste from city and dispose of at site. A bulldozer is used to level the waste right after the dumping operation. The dumping starts at 6 am in the morning and continues to $5 \mathrm{pm}$ at evening. Waste material is not buried so it is easily accessible to wildlife including avian species (Fig. 2).

Gondalawala landfill is located $8 \mathrm{~km}$ northwest to the city center (Fig. $1 \& 3$ ) with an area of $77,263 \mathrm{~m}^{2}$. The geography and location of this landfill is different from Chianwali landfill. It is situated on agricultural land and is characterized by presence of large pits left by the construction industry that sold excavated material (i.e. soil) leaving behind pits of depth up to $9 \mathrm{~m}$. No boundary wall is present around the landfill. The waste dumping timing, method, vehicles and bulldozer activity was observed to be the similar to the Chianwali landfill site. A single difference was absence of boundary wall that was present at Chianwali landfill site. In the absence of boundary wall, it is difficult to prevent the loose materials from flying off to surrounding agriculture land in windy conditions. More over the situation of 
people and traffic around the landfill was same as Chianwali due to pandemic (Fig. 3).

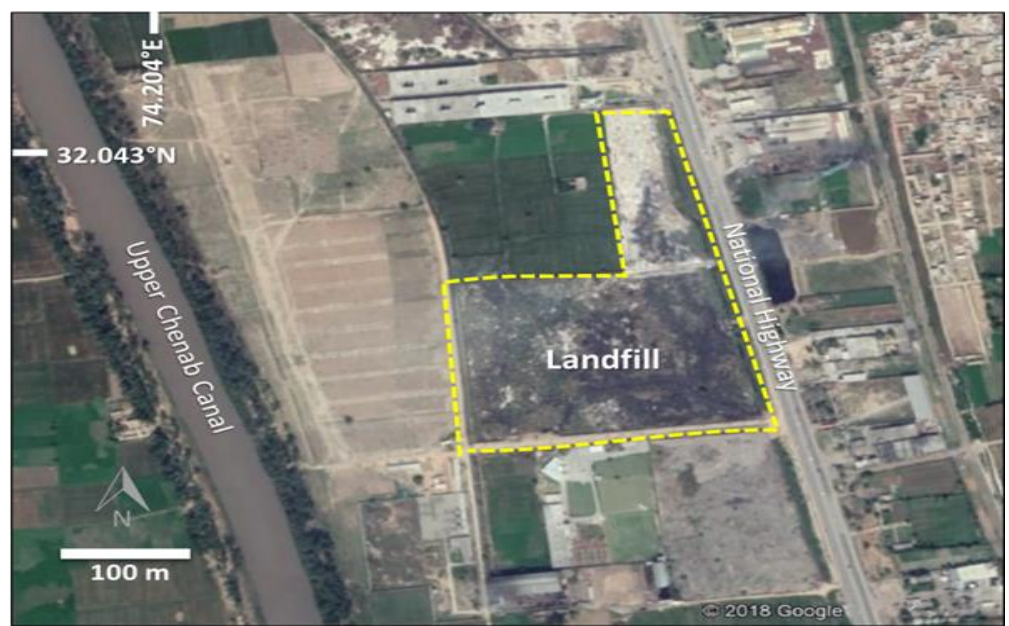

Figure 2. Map showing location of Chianwali landfill. Boundary of the landfill is marked by the broken line

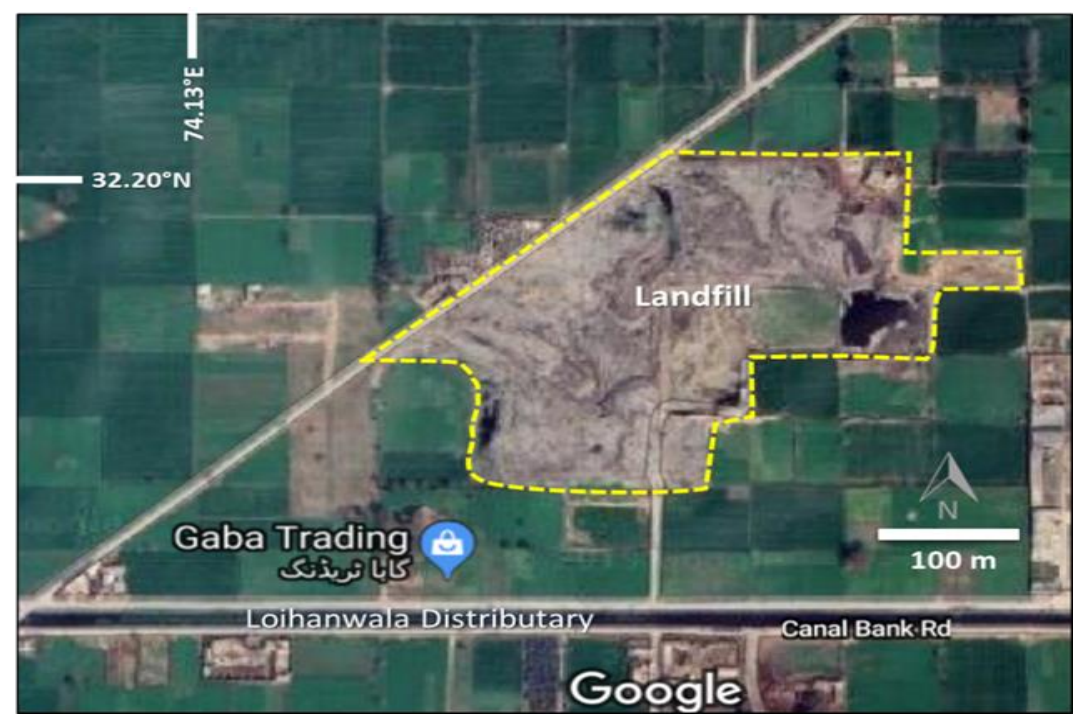

Figure 3. Map showing location of Gondalawala landfill

Field data collection and statistical analysis

Field observations were carried out at each landfill sites for 10 working days. A total count method was used for bird census after break of one hour from morning to evening [25] to record variations in number of birds with time of the day. The dominant behavior and activity pattern of bird species was observed at both landfills. The activity pattern of birds was divided into roosting on waste, sitting on land other than waste, sitting on trees at the periphery of waste, flying near the waste at low altitude $(>10 \mathrm{~m})$ and soaring high in the sky $(<30 \mathrm{~m})$. The dominant foraging pattern, i.e. place of foraging on waste was also observed. Field guide manuals were employed for the accurate identification of wild bird species. Statistical analysis of field data was done using various 
tools including SPSS. Images from the Google Earth were used to prepare location maps and the Geographic Information System (GIS) was employed to develop spatial distribution maps. The ShannonWiener diversity index ( $\left.\mathrm{H}^{\prime}\right) \mathrm{H}^{\prime}=-\left[\sum \mathrm{Pi} \ln \right.$ $\mathrm{Pi}$ [26] was used for the species diversity calculations. Species evenness (E) was calculated by $E=H^{\prime} / \operatorname{Logn} S$ [27]. Relative abundance of each species in population was determined by the formula $(\mathrm{Pi}) \mathrm{Pi}=\mathrm{Ni} / \mathrm{N}$.

\section{Results}

\section{Population at Chianwali landfill}

An average 17,374 birds of 15 species (S =15) were present at the Chianwali landfill site per day (taken average of five days). The diversity index $(\mathrm{H})$ was found to be 1.146 and the species evenness $(\mathrm{E})$ value was found to be 0.423 . Among the 15 species at the landfill, at the peak time of population i.e.7:00 am the Cattle egrets made 75\% ( $\mathrm{SD}=$ $12.4 \pm 8.6, N=1406$ ) of the total population of birds. The House crow was the second dominant species making $5 \%(\mathrm{SD}=9.6 \pm 6.7$, $N=101$ ) of the population of birds. Black kites made $5 \%(\mathrm{SD}=10 \pm 8, N=87)$ of the population of birds. The population of Common myna was found to be $3 \%$ ( $\mathrm{SD}=$ $3.7 \pm 3.3, N=59)$. The Plain martins registered $5 \%(\mathrm{SD}=7.6 \pm 4.1, N=91)$ and Sand martin made $3 \%(\mathrm{SD}=6.9 \pm 5.3, N=63)$ of the population. All other species contributed to less than $2 \%$ of the total population.

\section{Population at Gondalawala landfill}

It was observed that average 26,266 birds of 18 species $(S=18)$ were present at the Gondalawala landfill site per day. The diversity index $(\mathrm{H})$ was found to be 1.697 and the species evenness (E) value was found to be 0.587 . At the peak moment of population i.e. 7.30 am the Black kite was the most dominant species at this site making $55 \%$ ( $\mathrm{SD}=4.3 \pm 5.7, N=1842$ ) of the total bird population. House crow $(\mathrm{SD}=11.4 \pm 7.6, N=$ $371)$ and House sparrow $(\mathrm{SD}=6.4 \pm 4.5, N=$ 365 ) made $11 \%$ and $11 \%$ of the population of birds by each species, respectively. Plain martin registered $7 \%(\mathrm{SD}=13.4 \pm 9.5, N=$ 217 ) of the population. Bank myna made $6 \%$ (SD12.4 $\pm 6.57, N=187$ ) of the population of birds. Sand martin made 3\% ( $\mathrm{SD}=11.4 \pm 9.5$, $N=100)$ and Common myna made $3 \%$ ( $\mathrm{SD}=$ $5.4 \pm 4.7, N=81$ ) of population of birds. White wagtails made $1 \%(\mathrm{SD}=11.4 \pm 5.5, N=33)$ of the total population of birds.

\section{Activity pattern of avian species}

The activity pattern of birds was categorized depending upon behaviors such as presence at the waste surface, outside the waste dump, flying near the waste, soaring above the waste and sitting at the trees along the peripheries of both landfills (Table 1). At the Chianwali site, Cattle egrets $(69.9 \%$ population) were found to be sitting on the waste material most of the time. About 20\% of population remains flying on low altitude on waste. The $(7 \%)$ of population was found to be sitting on trees present in peripheries and sitting on ground other than landfill. Cattle egrets' aggressive behavior allowed a few birds of other species to sit on the waste surface for feeding. Black kites remained soaring in sky above the freshly dumped waste and dived down to pick food occasionally. No kite was found to be sitting on waste at this site. Common myna (39.9\%) of population and House crow $(46.1 \%)$ of population found to be sitting on the ground near waste. The $37.2 \%$ of population of House crow and $34.6 \%$ of Common myna remains flying near the waste and when get chance from the aggressiveness of egrets feed directly from waste. The situation was opposite on the Gondalawala landfill site. The Black kites were dominant at this landfill with $68.5 \%$ of population always roosting on the fresh waste. The $16 \%$ of population was soaring on the waste and kleptoparasitize crows on the running bulldozers for the food from the waste. The $13.8 \%$ of population remain flying near the waste. The $(9.2 \%)$ kites remain roosting on the trees dispersed 
on the peripheries of the landfill. At this landfill the Bank myna $87.1 \%$, of population, Common myna $75.7 \%$ and House crow $87.2 \%$ were remain feeding from the ground. The Black kites were less aggressive to these avian species as compared to egrets on the
Chianwali landfill site. The House sparrow was absent on the Chianwali landfill site but found to be present on Gondalawala. They remain flying on landfill $(79 \%)$ at lower height and $(21 \%)$ sitting on trees along the landfill site (Table 1).

Table 1. Activity pattern of dominant avian species found at two landfills

\begin{tabular}{|c|c|c|c|c|c|c|c|}
\hline $\begin{array}{c}\text { Landfill } \\
\text { site }\end{array}$ & $\begin{array}{l}\text { S. } \\
\text { No. }\end{array}$ & Bird Species & $\begin{array}{l}\text { Roosting } \\
\text { /feeding } \\
\text { on the } \\
\text { waste }\end{array}$ & $\begin{array}{c}\text { Flying } \\
\text { near the } \\
\text { surface of } \\
\text { waste }\end{array}$ & $\begin{array}{l}\text { Sitting on the } \\
\text { trees along the } \\
\text { boundaries } \\
\text { landfill }\end{array}$ & $\begin{array}{c}\text { Sitting on } \\
\text { edges } \\
\text { /ground/wires } \\
\text { and not on } \\
\text { the waste }\end{array}$ & $\begin{array}{l}\text { Soaring } \\
\text { high in } \\
\text { the sky }\end{array}$ \\
\hline \multirow{4}{*}{ 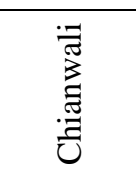 } & 1 & Cattle egrets & $69.60 \%$ & $19.9 \%$ & $7 \%$ & $4.70 \%$ & 0 \\
\hline & 2 & Black kite & 0 & $3.80 \%$ & $2.70 \%$ & $1.40 \%$ & $92.10 \%$ \\
\hline & 3 & House crow & $7.70 \%$ & $37.20 \%$ & $9 \%$ & $46.10 \%$ & 0 \\
\hline & 4 & Common myna & $13 \%$ & $34.60 \%$ & $2.30 \%$ & $49.90 \%$ & 0 \\
\hline \multirow{5}{*}{$\begin{array}{l}\frac{\pi}{\pi} \\
\frac{3}{0} \\
\frac{\pi}{\pi} \\
\frac{\pi}{0} \\
0 \\
0 \\
0\end{array}$} & 1 & Black kite & $63.50 \%$ & $13.80 \%$ & $5.20 \%$ & $2.50 \%$ & $16 \%$ \\
\hline & 2 & Bank myna & $87.10 \%$ & $4.80 \%$ & $4.70 \%$ & $3.40 \%$ & 0 \\
\hline & 3 & Common myna & $75.70 \%$ & $1.40 \%$ & $6.70 \%$ & $8.40 \%$ & 0 \\
\hline & 4 & House crow & $87.20 \%$ & $3.80 \%$ & 0 & $9 \%$ & 0 \\
\hline & 5 & House sparrow & $21 \%$ & $34.60 \%$ & $40 \%$ & $2.30 \%$ & 0 \\
\hline
\end{tabular}

\section{Time dependent variations}

Birds start to arrive at the landfills earlier than sunrise and reach their highest number in about an hour after sunrise (Fig. 4). However, there was a variation from this pattern at the Chianwali landfill as the birds started to arrive at the landfill after the sunrise 1-10 minute and reached a maximum number 1 to $1: 30$ minutes after the sunrise. After the peak values near the population started to decline and by the noon time (12 to $1: 30 \mathrm{pm}$ ) significantly less populations were present at both landfills, Gondalawala (39\%) and Chianwali $(71 \%)$. In the afternoon, populations started to increase and second peaks were observed but the values were lower than the morning peaks. A decline in population was observed again by the sunset. After the sunset the number of birds at the Chianwali landfill $(47.3 \%$ of total population) was many folds higher than the Gondalawala landfill $(3.1 \%$ of total population). No nocturnal data was taken at both landfills sites.

\section{Variation in feeding pattern}

Birds are divided into groups depending upon the feeding behaviors including insectivory, direct feeding and opportunity based feeding and not feeding from the waste. The feeding behavior of eight dominant bird species at both landfills is summarized in (Table 2). Cattle egrets, that were present only at the Chianwali site, fed all over the landfill and the feeding duration was much longer than any other specie $(\mathrm{t}=5$, df $=47, \mathrm{P}<0.001)$. Black kites showed different foraging behavior at both landfills. At the Chianwali landfill, they did not feed directly from the waste $(N=0)$ but at the Gondalawala landfill, however, they were foraging directly from the waste. Also, Black kites fed closer to the dumping vehicles during operation hours continuing till late. Common myna and Bank myna showed a similar feeding behavior. They had short feeding durations $(\mathrm{t}=1.5$, $\mathrm{df}$ $=39, \mathrm{P}>0.05)$ anywhere on the waste based on opportunity from the aggressiveness of kites at the Gondalawala sit and egrets at the Chianwali site. Plain martins and Sand martins were air born and remained flying on 
the landfill all the time with no significant difference in the feeding behavior. House sparrows were never found to be feeding at waste (Table 2).

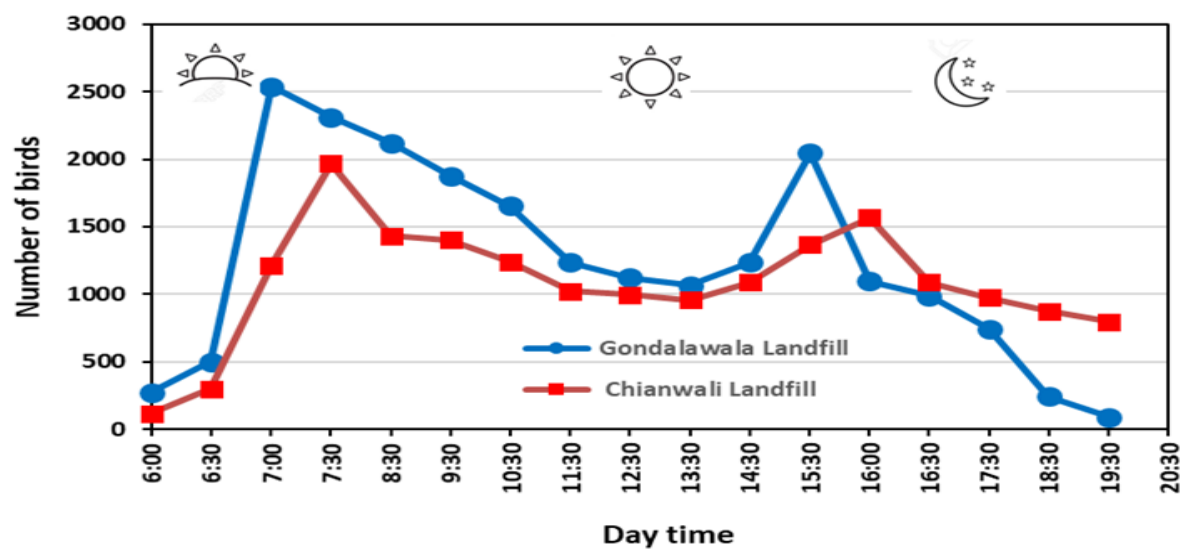

Figure 4. Time series plot illustrating data points at the regular intervals of daytime against bird's abundance at two landfills from sunrise to sunset

Table 2. Comparison of foraging activity of different avian species at two landfills

\begin{tabular}{|c|c|c|c|c|c|c|c|}
\hline $\begin{array}{c}\text { Name of } \\
\text { species }\end{array}$ & $\begin{array}{c}\text { Scientific } \\
\text { name }\end{array}$ & $\begin{array}{c}\text { Abundance } \\
\text { at } \\
\text { Gondalawala } \\
\text { landfill per } \\
\mathbf{1 0} \text { minute }\end{array}$ & $\begin{array}{c}\text { Abundance } \\
\text { at Chianwali } \\
\text { landfill per } \\
\mathbf{1 0} \text { minute }\end{array}$ & $\begin{array}{c}\text { Location of } \\
\text { feeding on } \\
\text { the dump }\end{array}$ & $\begin{array}{c}\text { Aggressive/ } \\
\text { non- } \\
\text { aggressive }\end{array}$ & $\begin{array}{c}\text { Feeding } \\
\text { duration }\end{array}$ & $\begin{array}{c}\text { Changes in } \\
\text { numbers } \\
\text { after } \\
\text { dumping } \\
\text { activity }\end{array}$ \\
\hline Black kite & $\begin{array}{c}\text { Milvus } \\
\text { migrans }\end{array}$ & 1842 & 87 & $\begin{array}{c}\text { Non } \\
\text { agressive at } \\
\text { Chianwali } \\
\text { but } \\
\text { waste } \\
\text { aggressive in } \\
\text { Gondalawala }\end{array}$ & Long & Decreased \\
\hline Bank myna & $\begin{array}{c}\text { Acridotheres } \\
\text { ginginianus }\end{array}$ & 187 & 0 & $\begin{array}{c}\text { Near fresh } \\
\text { waste }\end{array}$ & Aggressive & short & Increased \\
\hline Cattle egret & $\begin{array}{c}\text { Bubulcus } \\
\text { ibis }\end{array}$ & 0 & 1406 & Everywhere & Aggressive & Long & Decreased \\
\hline $\begin{array}{c}\text { Common } \\
\text { myna }\end{array}$ & $\begin{array}{c}\text { Acridotheres } \\
\text { tristis }\end{array}$ & 81 & 59 & Everywhere & Aggressive & Short & Decreased \\
\hline House crow & $\begin{array}{c}\text { Corvus } \\
\text { splendens }\end{array}$ & 371 & 101 & Everywhere & Aggressive & Short & Decreased \\
\hline $\begin{array}{c}\text { House } \\
\text { sparrow }\end{array}$ & $\begin{array}{c}\text { Passer } \\
\text { domesticus }\end{array}$ & 365 & 0 & Neutral & Neutral & No & No impact \\
\hline Plain martin & $\begin{array}{c}\text { Riparia } \\
\text { paludicola }\end{array}$ & 217 & 91 & $\begin{array}{c}\text { Air born } \\
\text { feeding }\end{array}$ & Neutral & $\begin{array}{c}\text { Air born } \\
\text { Feeding }\end{array}$ & No impact \\
\hline Sand martin & $\begin{array}{c}\text { Riparia } \\
\text { riparia }\end{array}$ & 100 & 63 & $\begin{array}{c}\text { Air born } \\
\text { feeding }\end{array}$ & Neutral & $\begin{array}{c}\text { Air born } \\
\text { feeding }\end{array}$ & No impact \\
\hline
\end{tabular}

\section{Discussion}

A huge population of birds was observed at both landfills (Fig. 5). Such abundance of birds is also observed at various landfills around the world $[2,21,28-30]$. Noreen and sultan [21] also observed the abundance of about 10,000 birds on landfill of Bhakrywali but the number of birds is four to five times higher at both landfills at this time of study. Probably the reason behind this is lock downs 
and shut down in the pandemic of COVID19. In the condition when human population was bound in homes it increased the access of birds to the landfill. Moreover, the disturbance level by traffic, Lorries, people was far less as compared to other days (before lockdown) which reduced the fear of birds and facilitated their aggregation in large number in area. Many studies conducted in many regions of the world showed significant changes on wild life due to COVID-19 where animals came in human territories due to lockdown of human beings. Probably, it is first study documenting huge aggregation of birds in area due to lockdown. Another finding in the study is significant variation in population of birds at two landfills (Fig. 5). The Gondalawala landfill was much richer in population of birds than Chianwali landfill. The reason behind this variation may be geographical location, accessibility of the birds to both landfills and presence of human disturbance. The geographic location of both landfills was different as Gondalawala is present around the agricultural lands in a rural setting. There was no disturbance except the noise of lorries, trollies taking waste from city and bulldozer that leveled the solid waste surface. The Chianwali landfill, on the other hand, is present along the Grand trunk road in a semi-urban area. The noise of traffic and presence of urban structure and people might be the reason of less number of birds on this landfill. Sol et al. [31] established that less number of birds were present at the landfill where there was noise and disturbance due to human activities. Noreen and Khawar [21] also established that less number of birds is present in cities (urban area) than agriculture areas so it may also be a reason for presence of a fewer numbers at the Chianwali landfill. The presence of boundary wall around this landfill may also reduce the accessibility of food to birds from the waste so a few birds were present here. Olea \& Baglione [18] also found that if access of birds is limited, population is decreased at the landfills. Similarly, Weiser \& Powell [32] found that diet of birds consists of garbage up to $85 \%$ if there is an access in proximity of $10 \mathrm{~km}$ to landfill and vice versa (Fig. 5).

There was not a significant difference in avian diversity at two landfills. Many opportunist species i.e. House crow, Black kites, Common myna, Plain martin, Sand martin were present abundantly at both landfills. The presence of these opportunist species i.e. House crow [8, 33], Black kites [33-35] Common myna [8] has already been established on different landfills of world but Noreen and khawar [21] reported presence of these all species along with Plain Martin Sand martin on landfill of Bhakrywali, Gujranwala. The Cattle egrets were not reported earlier in Pakistan [21] but first time reported on the landfill of Chianwali in Gujranwala, Pakistan.

Among the all species, Black kites dominated the Gondalawala landfill site (Fig. 6 \& Fig. 7(e)). Black kites use landfills as foraging and roosting sites in many other areas of the world. A huge number of 847 Black kites were reported on refuse dumps in Madrid, Spain with the higher abundance in autumn season when natural food resources are scarcer [36]. This abundance of Black kites has also been observed on waste dumps of Rome with the number of kites increasing after breeding season and found in foraging from dawn to dusk [35]. At the Gondalawala landfill site the huge number of Black kites were present after the breeding season is over same as in Madrid but their number was much higher than Madrid. The feeding of kites after the breeding season is over may be same as in Madrid and Rome. Thus landfills may be being used as alternative food source to kites in this season and shifted their diets to garbage from natural rich resources. The Cattle egrets were dominant species at the Chianwali landfill site (Fig. 5 \& Fig. 7(e)). 
Their presence in huge number has also been reported on different landfills of the world [8, 19, 20, 37], Pomeroy [19] and Marasinghe et al [8] reported their presence in huge number on the landfills of Uganda and Sri lanka engaged in insectivory but they are also reported in eating garbage from the landfills of Florida and Uganda [20, 37]. On the landfill of Chianwali the egrets are found in garbage eating clearly. In the previous studies no one has differentiated their breeding or non-breeding population on landfill. On the landfill of Chianwali the $98 \%$ of population of cattle egrets was non-breeding. The sampling was done in non- breeding season (Fig. 6).

This was similarity in kites and egrets that both species were using two landfills in nonbreeding season. The populations of many other avian species like different species of gulls also reported to use landfill in nonbreeding season $[16,38]$. It was also found that in Glaucous gulls (Larus hyperboreus) the non-breeding population uses landfill more frequently than adult breeding population [32]. Similarly, Gilbert et al. [12] reported that white storks non-breeding population showed $43 \%$ more garbage than breeding population pointing to its high dependency on garbage. In this study the kites and egrets both have non-breeding populations dominant at both landfills showing a character similar to gulls and storks in the other regions of the world. Noreen and sultan [21] found that at Bhakrywali landfill dominant species were common myna followed by House crow but it is hypothesized here that the dominancy of Cattle egrets and Black kite is because of absence of human in the area because of lockdowns. If this would be not a reason they must be present at Bhakrywali landfill [21] only $5 \mathrm{~km}$ away from Gondalawala in such a huge abundance one year ago.

The bird's population started to increase on both landfills after the sunrise and reached maximum level in the morning time followed by a rapid decline in the noon time (Fig. 4). A second peak of population abundance was observed about two hours before the sunset. But a variation was observed at both landfills before sunrise and after sunset. At Gondalawala the birds started to arrive before surmise and their number declined rapidly after the sunset but at the Chianwali they started to arrive after sunrise and remain present even two hours after the sunset. Sol et al. [31] also reported that the feeding activity of birds may vary among landfills present in the same geographic location. It is also studied that at different landfills of the world different feeding timings of birds have also been observed. The feeding from dawn to dusk [35] and in some cases 24 hours foraging even in moonlight has also been observed [39]. The possible reason for the presence of birds after the sunset at Chianwali landfill can be explained by its location in urban area. At the Gondalawala landfill site there are no manmade lights after the sunset so birds' number declined rapidly perhaps due to darkness but at the Chianwali landfill after many hours of sunset manmade lights from the buildings, roadside poles and vehicle headlights are always present. This light made visibility better so birds were present until late. Burger [39] also reported similar situation that birds feed in the artificial lights and even in moonlights with equal ease as in day light, which can explain the reason for the presence of birds on the landfill of Chianwali. The other reason may be the preference in feeding behavior of species. Kites usually leave waste dumps with dusk [35] which was also observed in Gondalawala but presence and night foraging of egrets may be their similar behavior to other gulls species as observed in other regions of the world or due to unknown reason. Further research is required to explain this behavior of species at landfills (Fig. 4). 
Avian species present at both landfills were divided into groups based on unique characteristics of foraging behaviors. Spatial distribution maps are shown in (Fig. 7a-e). The first group is a set of bird species present on both landfills in more or less in similar abundance (Fig. 7).

These species are Red-wattled lapwing, (Vanellus indicus) Indian pond heron, (Ardeola grayii) Green bee eater, (Merops orientalis) White throated kingfisher, (Halcyon smyrnensis) Red-vented bulbul, (Pycnonotus cafer) Black drongo (Dicrurus macrocercus) and Laughing dove (Spilopelia senegalensis). A few of these species are passerines, which visit landfills not for direct feeding but for some other unknown purpose (e.g. nest building material). This type of behavior has already been established in landfills of the world $[6,40]$. At the landfill of Gondalawala the passerines (e.g. House sparrow) were flying over the landfill waste and sitting on the trees around the landfill area but no feeding was observed. Burger $\&$ Gochfeld, [37] reported that passerines feed on the edges on landfill while Gabrey [6] reported that the passerines sit on shrubs present on peripheries of the landfill. Here presence of passerine was observed but contrary to Burger \& Gochfeld, [37] no feeding was recorded.

The second group is composed of wild avifauna found to be present at one landfill site but absent at the other. Asian koel (Eudynamys scolopaceus), House sparrow, Indian golden eagle, (Aquila chrysaetos) White wagtails (Motacilla alba) and Wired tailed swallow (Hirundo smithii) were present on Gondalawala but absent at the
Chianwali landfill. Similarly, Common babblers (Argya caudate) were seen foraging at the Chianwali but absent at the Gondalawala site. This may be due to the preference of species depending upon the geographical location and ease of accessibility to food items.

The third group consists of opportunist species like mynas and crows that showed similar foraging behavior on both landfills (Fig. 7(c)). The two species of mynas, i.e. Bank myna \& Common myna, feed wherever they find space on the landfill. Burger \& Gochfeld [37] found that starlings feed on edges of landfill. Starlings and mynas are related to each other but a difference is observed in the feeding behavior at the landfill of Florida and the study area. In this study, mynas were found sitting on edges but fed anywhere they find opportunity from the aggressiveness of egrets and kites. House crows also feed wherever they find opportunity. Their opportunist behavior is already established in other parts of the world $[8,33]$.

The fourth group of birds is insectivore such as martins (House, Plain \& Sand martins) that were found to be feeding on insects at both landfills (Fig. 7(d)). Martins have an insectivorous diet (e. g. flies, moths, mosquitoes) and eat most of their prey in midair while flying over landfill waste [41]. These species have not been reported earlier at any landfill [42] in the world but Noreen and Sultan [21] reported their presence at landfill of Bhakrywali (Gujranwala, Punjab) in the same region feeding on insects (mosquitoes and flies). 


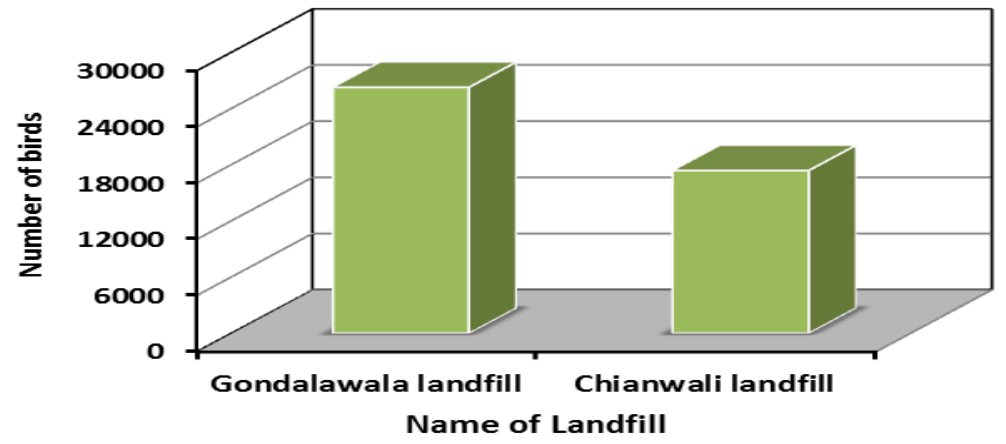

Figure 5. Comparison of number of birds at two landfills
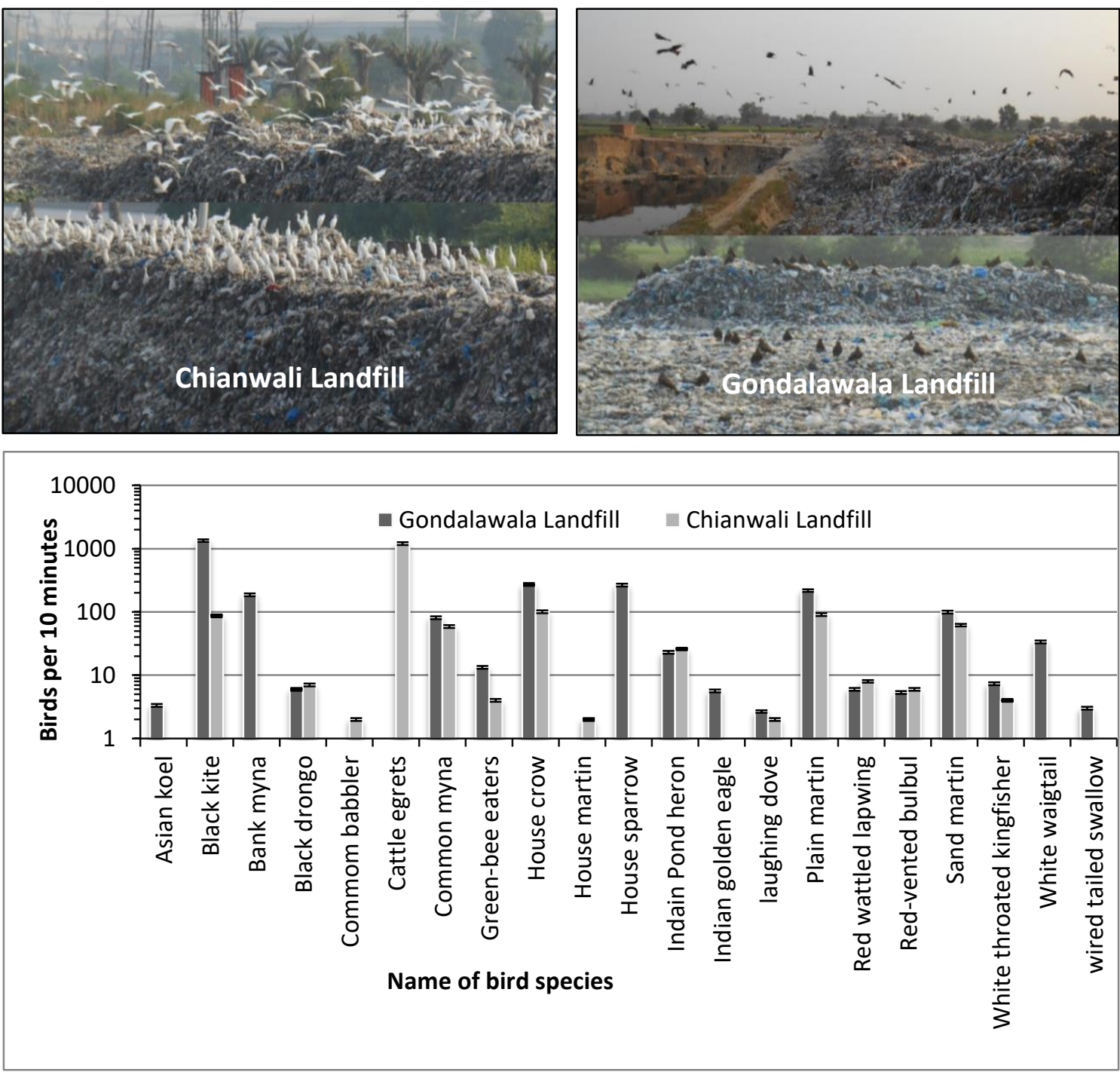

Figure 6. Error bar graph showing population of 21 bird species at two landfills. Photos showing non-breeding population of cattle egrets at the Chianwali landfill and Black kites at the Gondalawala landfill 

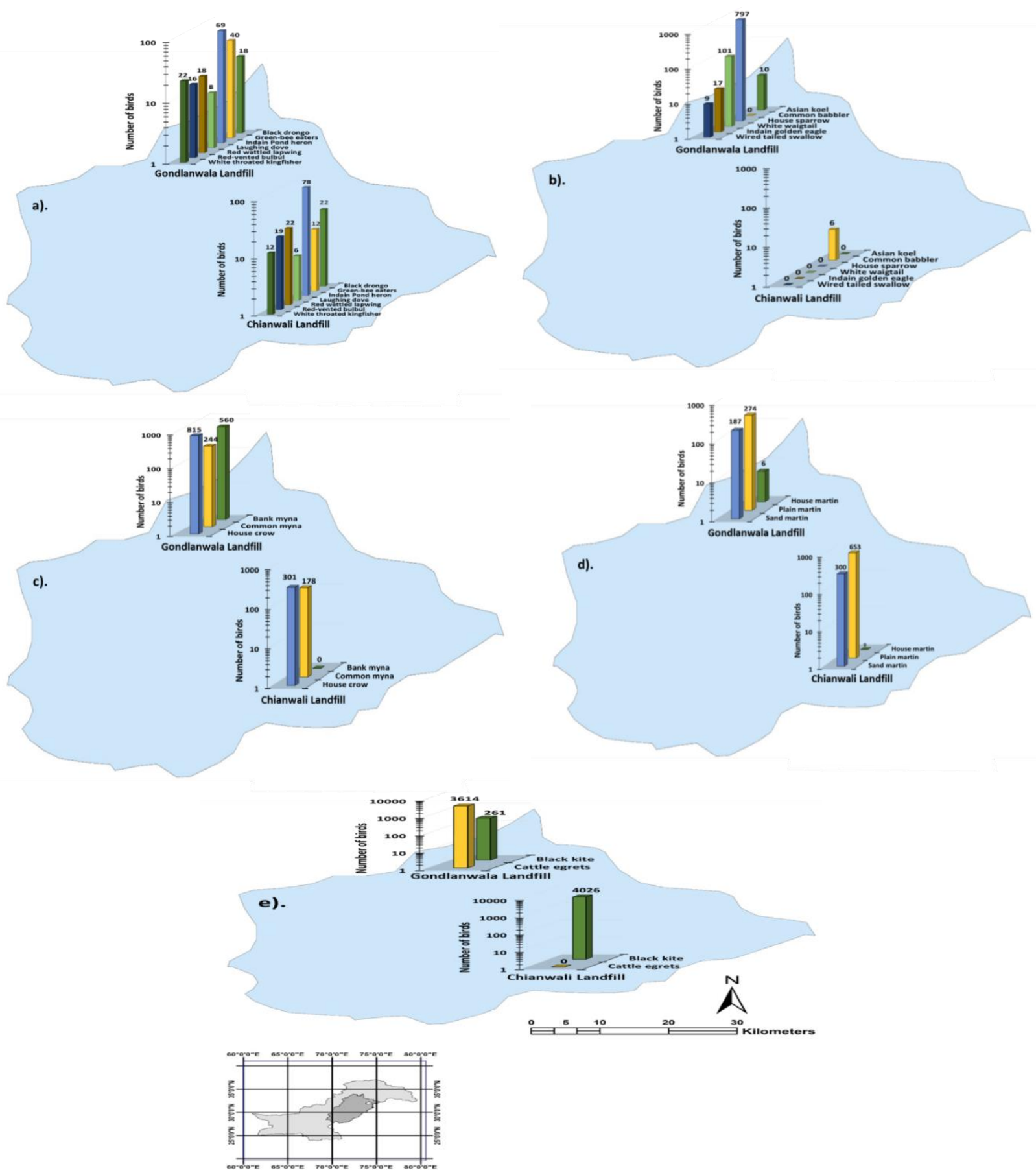

Figure 7. Abundance at two landfills of the Gujranwala area. Seven species did not register significant changes in numbers at two landfills (a). Certain bird species were found to be at one landfill but absent at the other landfill (b). A set of bird species showing aggress behavior in feeding (c). An insectivore group of birds was present at both landfills (d). The most dominant group of birds (Cattle egret \& Black kite) in terms of numbers varied significantly (e) 


\section{Conclusion}

It is found that each landfill is specific in its characteristics and maintains particular set of avifauna composition. The huge population of birds was present at two landfills due to presence of a few human beings in area due to lockdowns in the pandemic of covid-1. The pattern of use of landfills in the morning and evening was different and most possibly due to the landfill management practices such as artificial lights that facilitated the visibility, hence, birds' presence at Chianwali stayed 2 to 3 hours after the dusk. This pattern was not observed at Gondalawala landfill. The dominant species was also different as Black kites at the Gondalawala and Cattle egrets at the Chianwali site establishing their own niche and never allowing other species to use landfill in large numbers. Their presence in huge number than previous studies in lockdown days shows that these birds can occupy the area in absence of human from the area and if lockdown/shutdown prolongs we can see many other avian species in the region present abundantly. The similarities among the both landfills are presence of opportunist species House crow and Common myna in equal ratio at two landfills. They find opportunity and start feeding everywhere at both sites. Some airborne species like martins (House, Plain \& Sand) were found in insectivory on both sites. Several other bird species were present in similar ratios at both sites. So it is concluded that each landfill has its own characteristics habitat and trend at one site may not be generalized at other landfills whether present in geographically same area and also, local short term changes in environment like weather patterns or pandemics (lock down/shut down) can also have huge impact on birds even at places like landfills.

\section{Authors' contributions}

Conceived and designed the experiments: $\mathrm{Z}$ Noreen \& K Sultan, Performed the experiments: $\mathrm{Z}$ Noreen, Analyzed the data: $\mathrm{Z}$
Noreen, Contributed materials/ analysis/ tools: Z Noreen \& K Sultan, Wrote the paper: Z Noreen \& K Sultan.

\section{Acknowledgement}

We thank Mr. Khushi Muhammad and Mr. Muhammad irfan for their assistance with the fieldwork during sunrise, noon and sunset times. We are also immensely thankful to $\mathrm{Mr}$. Imran raza and Khubaib hasan for providing instruments for the field work. We also thank to field managers and employees of GWMC at both landfills that facilitated research work during the landfill visits.

\section{References}

1. Mudge GP \& Ferns PN (1982). The feeding ecology of five species of gulls (Ayes: Larini) in the inner Bristol Channel. J Zool 197: 497-510.

2. Jordi O, Herrero A, Aldalur A, Cuadrado JF \& Arizaga J (2014). The impact of non-local birds on yellow-legged gulls (Larus michahellis) in the Bay of Biscay: a dump-based assessment. Anim Biodiv Conserv 37: 183-190.

3. Inigo-Elías, EE (1987). Feeding habits and ingestion of synthetic products in a black vulture population from chiapas, mexico. Acta Zool Mex 22: 1-15.

4. Calle L \& Gawlik DE (2011). Anthropogenic food in the diet of the Sacred Ibis (Threskiornis aethiopicus), a non-native wading bird in southeastern Florida, USA. Fla Field Nat 39: 1-15.

5. Pons JM \& Migot P (1995). Life-history strategy of the herring gull: changes in survival and fecundity in a population subjected to various feeding conditions. $J$ Anim Ecol 64: 592-599.

6. Gabrey SW (1997). Bird and small mammal abundance at four types of waste-management facilities in northeast Ohio. Landsc Urban Plan 37: 223-233.

7. Belant JL, Ickes SK \& Seamans TW (1998). Importance of landfills to urbannesting herring and ring-billed gulls. Landsc Urban Plan 43:11-19. 
8. Marasinghe SS, Perera PK \& Dayawansa PN (2018). Putrescible Waste Landfills as Bird Habitats in Urban Cities: A case from an Urban Landfill in the Colombo District of Sri Lanka. J Trop Forest and Envir 8(2): 29-41.

9. Houston DC, Mee A \& McGrady M (2007). Why do condors and vultures eat junk? The implications for conservation. J Raptor Res 41: 235-238.

10. Tauler-Ametller H, Matías HA, Parés F, Pretus JL \& Real J (2018). Assessing the applicability of stable isotope analysis to determine the contribution of landfills to vultures' diet. Plos One 13(5): e0196044.

11. Tortosa FS, Caballero JM \& ReyesLópez J (2002). Effect of rubbish dumps on breeding success in the White Stork in southern Spain. Waterbirds 25:39-43.

12. Gilbert I, Correia RA, Silva JP, Pacheco C, Catry I, Atkinson PW \& Franc AM (2016). Are white storks addicted to junk food? Impacts of landfill use on the movement and behaviour of resident white storks (Ciconia ciconia) from a partially migratory population. Mov Ecol 4:1-13.

13. Torres-Mura JC Lemus M L \& Hertel F (2015). Plastic material in the diet of the Turkey vulture (Cathartes aura) in the Atacama Desert, Chile. Wilson J Ornithol 127: 134-138.

14. Burger J, Fitch M, Shugart G \& Werther W (1980). Piracy in Larus gulls at a dump in New Jersey. In Proceedings of the Colonial Waterbird Group. Col Waterbirds 3: 87-98.

15. Sazima I (2007). From carrion-eaters to bathers' bags plunderers: how Black Vultures (Coragyps atratus) could have found that plastic bags may contain food. Rev Bras Ornitol 15: 617-620.

16. Horton N, Brough $\mathrm{T} \&$ Rochard JBA (1983). The importance of refuse tips to gulls wintering in an inland area of southeast England. J Appl Ecol 20: 751-765.
17. Novaes WG \& Cintra R (2015). Anthropogenic features influencing occurrence of Black Vultures (Coragypsatratus) and Turkey Vultures (Cathartes aura) in an urban area in central Amazonian Brazil. Condor 117(4): 650-659.

18. Olea PP \& Baglione V (2008). Population trends of Rooks Corvus frugilegus in Spain and the importance of refuse tips. Ibis 150(1): 98-109.

19. Pomeroy DE (1975) Birds as scavengers of refuse in Uganda. Ibis 117(1) 69-81.

20. Annorbah NN \& Holbech LH (2012). Relative abundance, agonistic behaviour, and resource partitioning among three scavenging bird species in Ghana. Malimbus 34: 1-8.

21. Noreen Z \& Sultan K (2020). Population Explosion and Behavioural Changes of Opportunist Wild Avifauna at a Landfill at Gujranwala in Northeastern Punjab: A Baseline Deviation Study. Pak J Zool 53:1-13.

22. Geiger R (1961). Überarbeitete Neuausgabe von Geiger, R. KöppenGeiger/Klima der Erde.Wandkarte 1: 16 Mill.-Klett-Perthes, Gotha.

23. Anjum WA, Ahmad SR, Sanaullah M, Majid Z \& Mirza K (2016). Geographic Information System and Modeling Approach for Groundwater Systems of Rechna Doab, Pakistan. Pak J Sci 68(4): 470.

24. GWMC (2018). Gujranwala Waste Management Company. Environmental and social consideration survey. Integrated solid waste management master plan for Gujranwala. Retrieved from: www.gwmc.com.pk

25. Blondel C, Ferry C \& b Frochot B (1970). La méthode des indices ponctuels d'abondance (i.p.a.) ou des relevés d'avifaune par stations d'écoute. Alauda 38: $55-71$. 
26. Shannon CE \& Weaver W (1963). The Mathematical Theory of Communication. The University of Illinois Press, $16^{\text {th }}$ Edition, Illinois.

27. Pielou EC (1966). The measurement of diversity in different types of biological collections. J Theoret Biol 13:131-144.

28. Vidal E, Medail F \& Tatoni T (1998). Is the yellow-legged gull a superabundant bird species in the Mediterranean? Impact on fauna and flora, conservation measures and research priorities. Biodivers Conserv 7: 1013-1026.

29. Ramos R Ramírez F Sanpera C Jover L, \& Ruiz X (2009). Diet of Yellow-legged Gull (Larusmichahellis) chicks along the Spanish Western Mediterranean coast: the relevance of refuse dumps. J Ornithol 150: 265-272.

30. Washburn BE, Lowney MS \& Gosser AL (2012). Historical and current status ofLaughing Gulls breeding in New York State. Wilson J Ornithol 124: 525-530.

31. Sol D, Arcos JM \& Senar JC (1995). The influence of refuse tips on the winter distribution of Yellow-legged Gulls Laruscachinnans. Bird Study 42: 216221.

32. Weiser EL \& Powell AN (2010). Does garbage in the diet improve reproductive output of Glaucous Gulls? Condor 112: 530-538.

33. Plaza PI \& Lambertucci SA (2017). How garbage are dumps impacting vertebrate demography, health, and conservation. Glob Ecol Conserv 12: 9-20.

34. Blanco G (1997). Role of refuse as food for migrant, floater and breeding Black
Kites (Milvus migrans). J Raptor Res 31: 71-76.

35. Giacomo U \& Guerrieri $G$ (2008). The feeding behavior of the Black Kite (Milvus migrans) in the rubbish dump of Rome. J Raptor Res 42: 110-118.

36. Blanco G (1994). Seasonal abundance of Black Kites associated with the rubbish dump of Madrid, Spain. J Raptor Res 28: 242-245.

37. Burger J \& Gochfeld M (1983). Behavior of nine avian species at a Florida garbage dump. Col Waterbirds 6: 54-63.

38. Belant JL, Seamans TW, Gabrey SW \& Ickes SK (1993). Importance of landfills to nesting herring gulls. Condor 95: 817830.

39. Burger J (2001). Landfills, nocturnal foraging, and risk to aircraft. $J$ Toxicol Environ 64: 273-290.

40. Francoeur L \& Lowney M (1997). Bird abundance at accomack county southern landfill, melfa, Virginia, in relation to various management activities. In: Proceedings of the Eighth Eastern Wildlife Damage Management Conference 8: 140-151.

41. Arena S, Battisti C \& Carpaneto GM (2011). The ecological importance of wetlands for aerial insectivores (swifts, martins and swallows) along the Tyrrhenian coast. Rend Fis Acc Lincei 22: 395-402.

42. Noreen Z \& Sultan K (2020) A global modification in avifaunal behavior by use of waste disposal sites (waste dumps/rubbish dumps): A review paper. Pure Appl Biol 10(3): 603-616. 